\title{
The Incidence of Wolbachia Bacterial Endosymbiont in Bisexual and Parthenogenetic Populations of the Psyllid Genus Cacopsylla (Hemiptera, Psylloidea)
}

\author{
Nazar A. Shapoval ${ }^{1, *} \mathbb{0}$, Seppo Nokkala ${ }^{2}$, Christina Nokkala ${ }^{2}$, Galina N. Kuftina ${ }^{1}(\mathbb{D}$ \\ and Valentina G. Kuznetsova ${ }^{1, *}$ \\ 1 Department of Karyosystematics, Zoological Institute, Russian Academy of Sciences, Universitetskaya nab. 1, \\ 199034 Saint-Petersburg, Russia; galinakuftina@mail.ru \\ 2 Laboratory of Genetics, Department of Biology, University of Turku, FI-20014 Turku, Finland; \\ sepnok@utu.fi (S.N.); chrinok@utu.fi (C.N.) \\ * Correspondence: nazaret@bk.ru (N.A.S.); valentina.kuznetsova@zin.ru (V.G.K.)
}

check for updates

Citation: Shapoval, N.A.; Nokkala, S.; Nokkala, C.; Kuftina, G.N.; Kuznetsova, V.G. The Incidence of Wolbachia Bacterial Endosymbiont in Bisexual and Parthenogenetic Populations of the Psyllid Genus Cacopsylla (Hemiptera, Psylloidea). Insects 2021, 12, 853. https://doi.org/ $10.3390 /$ insects 12100853

Academic Editor: Ann Fallon

Received: 5 September 2021

Accepted: 18 September 2021

Published: 22 September 2021

Publisher's Note: MDPI stays neutral with regard to jurisdictional claims in published maps and institutional affiliations.

Copyright: (C) 2021 by the authors Licensee MDPI, Basel, Switzerland This article is an open access article distributed under the terms and conditions of the Creative Commons Attribution (CC BY) license (https:// creativecommons.org/licenses/by/ $4.0 /)$.
Simple Summary: Wolbachia has many varied impacts on the biology and evolution of insects and some other groups of invertebrates. The number of studies that have particularly addressed the impact of Wolbachia infection on reproduction and processes of speciation and diversification of host species has grown rapidly over the past decade. Despite that, our current knowledge on Wolbachia is limited, and comprehensive large-scale biogeographical studies devoted to the incidence of Wolbachia within a certain taxon or groups of taxa, although they are of great importance, are still scarce. In the present study, we focused on several Palaearctic Cacopsylla (Hemiptera, Psylloidea) species with different (parthenogenetic and bisexual) reproductive strategies. We conducted PCR screening of 526 specimens collected in different geographical regions of Europe and Russia in order to estimate a broad pattern of Wolbachia incidence and prevalence of five Cacopsylla species, Cacopsylla. borealis, Cacopsylla. lapponica, Cacopsylla. myrtilli, Cacopsylla. ledi, and Cacopsylla. fraudatrix. We revealed significant differences in infection frequencies between the species and even distinct populations of the same species, which, however, did not correlate with reproduction strategy or gender. These findings provide a starting point for understanding the role of Wolbachia infection in Cacopsylla evolution and diversity.

Abstract: Wolbachia is one of the most common intracellular bacteria; it infects a wide variety of insects, other arthropods, and some nematodes. Wolbachia is ordinarily transmitted vertically from mother to offspring and can manipulate physiology and reproduction of their hosts in different ways, e.g., induce feminization, male killing, and parthenogenesis. Despite the great interest in Wolbachia, many aspects of its biology remain unclear and its incidence across many insect orders, including Hemiptera, is still poorly understood. In this report, we present data on Wolbachia infection in five jumping plant-lice species (Hemiptera, Psylloidea) of the genus Cacopsylla Ossiannilsson, 1970 with different reproductive strategies and test the hypothesis that Wolbachia mediates parthenogenetic and bisexual patterns observed in some Cacopsylla species. We show that the five species studied are infected with a single Wolbachia strain, belonging to the supergroup B. This strain has also been found in different insect orders (Lepidoptera, Hemiptera, Plecoptera, Orthoptera, Hymenoptera, Diptera) and even in acariform mites (Trombidiformes), suggesting extensive horizontal transmission of Wolbachia between representatives of these taxa. Our survey did not reveal significant differences in infection frequency between parthenogenetic and bisexual populations or between males and females within bisexual populations. However, infection rate varied notably in different Cacopsylla species or within distinct populations of the same species. Overall, we demonstrate that Wolbachia infects a high proportion of Cacopsylla individuals and populations, suggesting the essential role of this bacterium in their biology.

Keywords: Wolbachia infection; phylogeography; infection frequency; PCR screening; bisexual reproduction; parthenogenesis; jumping plant-lice 


\section{Introduction}

Wolbachia Hertig 1936 is a diverse genus of intracellular rickettsia bacteria (Alphaproteobacteria: Rickettsiales: Rickettsiaceae) that infects invertebrates, namely arthropods and nematodes [1]. Representatives of the genus were found for the first time in 1924 by M. Hertig and S. Wolbach [2] in the mosquito Culex pipiens Linnaeus, 1758. Subsequently, the type species for the Wolbachia genus, W. pipientis Hertig, 1936, was formally described [3]. Wolbachia is considered one of the most common and widespread endosymbiotic bacterium so far discovered, infecting a broad range of hosts. Estimates suggest that more than $65 \%$ of all insect species are infected with Wolbachia and these bacteria are also characteristic of other arthropods, such as arachnids and crustaceans, and of nematodes [4-6]. Wolbachia is genetically diverse and, as of now, is generally divided into 16-17 main monophyletic lineages = "supergroups" (A to S) [7]. Members of some supergroups are exclusively found in filarial (C, D, J) or plant (L) parasitic nematodes [8-12], whereas supergroup F consists of strains infecting both nematodes and arthropods [13,14]. Members of all other supergroups (clades $\mathrm{G}$ and $\mathrm{R}$ are now considered to be part of the supergroups B and A, respectively [15]) infect only arthropods [16-20].

Wolbachia is mainly transmitted vertically from mother to offspring, while its lateral or horizontal transmission between host species has also been recorded [5,21-24]. Wolbachia strains associated with nematodes generally evolve mutualistic interactions with their hosts. In some filarial nematodes, Wolbachia bacteria are beneficial to the host and treated as primary (obligate) symbionts that have coevolved from ancient associations; they show within and among species prevalence and co-phylogeny with the host. In these associations, Wolbachia seems to be exclusively vertically transmitted, which is regarded as a sign of host-provided benefits [25]. Wolbachia members involved in relationships with insects and other arthropods may have no evident impact on their hosts; however, in some cases they are able to distort host sex ratios toward females. Their prevalence varies within and among taxa, showing no co-speciation events. The only proven exception to this rule is the common bedbug Cimex lectularius Linnaeus, 1758 (Hemiptera). This species, and probably its congeners, have demonstrated beneficial relationships with Wolbachia, which are based on mutualistic nutritional provision and co-cladogenesis with it [26].

Wolbachia endosymbionts are usually present in the reproductive tissues of the host species. Their effects include feminization of genetic males, that develop as females (this phenomenon is common in isopod crustaceans and in insect orders Lepidoptera and Hemiptera); male killing - elimination of male progeny to improve the surviving advantage of infected female siblings (insect orders Diptera, Coleoptera, and Lepidoptera, and also arachnid order Pseudoscorpiones); sperm-egg cytoplasmic incompatibilityunsuccessful mating of infected males with uninfected females or females that harbor different Wolbachia strains (Acari, Isopoda, and insect orders Coleoptera, Diptera, Hemiptera, Hymenoptera, Lepidoptera, and Orthoptera); parthenogenetic induction (=Wolbachia-induced thelytokous parthenogenesis) - development of unfertilized eggs and elimination of males from reproduction (Acari, Hymenoptera, Thysanoptera). In addition to the well-known effects listed above, infection with Wolbachia is known to cause changes at the cytological level, such as defects in chromosome condensation and segregation, disfunction of the centrosome, delays in mitotic progression, and nuclear envelope breakdown $[27,28]$. In some cases, infection provides a fitness benefit to the host. As observations of Drosophila melanogaster Meigen, 1830 suggest, infected females show an increased frequency of meiotic recombination and higher reproductive output than Wolbachia-free flies [29]. Recent reports on isopod species suggested that Wolbachia-to-host horizontal genome transfer may cause the evolutionary transitions in sex chromosome systems in animals, including the emergence of sex chromosomes de novo [24,30].

Wolbachia is characterized by relatively small genome size $(1.08-1.7 \mathrm{Mb})$. Such reduction of the genome is typical for the Rickettsiales and most likely developed as a host adaptation. Assembling of Wolbachia genomes revealed that parasitic strains may contain a high number of repetitive and mobile elements [31]. In contrast, mutualistic filarial 
nematode Wolbachia lacks repetitive elements, or their number is significantly reduced [32]. Another remarkable feature is that Wolbachia possesses a high level of nucleotide divergence, in certain genes (e.g., wsp gene) exceeding 43\%. Such remarkable genetic diversity could be explained by the extensive recombination between distinct strains. Both features, a large amount of repetitive DNA and high recombination rates of various regions of the genome, may be actively selected as a mechanism that facilitates successful establishment of parasitic Wolbachia within novel host lineages after horizontal transmission. Some of these highly divergent genes (e.g., wsp gene coding Wolbachia surface proteins and its two paralogues, $w s p A$ and $w s p B$ ) together with $16 S r R N A$ and ftsZ genes traditionally serve as molecular markers to detect Wolbachia infection [33].

Jumping plant-lice or psyllids (Psylloidea) are classified as a superfamily of Sternorrhyncha (Hemiptera), comprising over 3800 described species of small plant-sap feeding insects [34]. Several psyllid species, such as the Asian citrus psyllid Diaphorina citri Kuwayama, 1908 (Liviidae), Mycopsylla spp. (Homotomidae), and Psyllopsis spp. (Psyllidae) have been shown to be infected with Wolbachia $[35,36]$. For example, all 15 sampled populations of D. citri in Brazil were completely infected with Wolbachia [35].

Cacopsylla Ossiannilsson, 1970 is one of the largest psyllid genera, with approximately 170 described taxa associated with woody dicotyledonous plants, consistent with the majority of psyllids in general. The genus has a predominantly Holarctic distribution with a few species occurring in the Afrotropical, Oriental, and Australasian biogeographical regions [37-39]. A series of Cacopsylla species possesses a kind of reproductive strategy where, in some populations, males and females are equally abundant, in other populations males are exclusively rare, and in some further populations only females are found [40-48]. The genus Cacopsylla offers, thus, an attractive model system to investigate the co-existence of different reproductive modes within a particular species and to appreciate the possible role of Wolbachia in transitions from bisexual to unisexual reproduction.

In the present study, we examined the prevalence (proportion of infected individuals) of Wolbachia infection in different populations of five Cacopsylla species with various life strategies, namely C. myrtilli (Wagner, 1947), C. ledi (Flor, 1861), C. fraudatrix Labina et Kuznetsova, 2012, C. borealis Nokkala et Nokkala, 2019, and C. lapponica Nokkala et Nokkala, 2019. The Holarctic boreo-alpine species, C. myrtilli and C. ledi, are strongly female-biased parthenogenetic species, albeit males at a very low frequency may occur in certain populations $[43-46,48]$. Females of these species are generally triploid with $2 n=3 x=36+X X X$, while our recent studies revealed presence of diploid females with $2 n=24+X X$ among the triploids in several populations of these species $[45,46]$. C. fraudatrix, described from the Bieszczady Mountains, Poland, and C. lapponica, a rare alpine taxon restricted to a high-altitude open habitat, represent a truly bisexual species with $2 \mathrm{n}=24+\mathrm{XX} / \mathrm{X}(0)$, demonstrating nearly equal sex ratio $[47,49]$. Finally, a widely distributed species $C$. borealis is pentaploid, with apomictic females displaying $2 n=5 x=60+X X X X X$ [47].

A key question that we address here is: are the parthenogenetic and bisexual patterns observed in different Cacopsylla species and even within distinct populations of the same species related to Wolbachia infection? If we assume this, we could expect broad distribution and high infection frequency within parthenogenetic populations/species and, on the contrary, absence or significantly lower Wolbachia prevalence in bisexual entities.

\section{Materials and Methods}

\subsection{Taxon Sampling, Wolbachia Screening, and Sequencing}

To examine the patterns of Wolbachia infection, 526 specimens belonging to five Cacopsylla species (C. borealis, C. lapponica, C. myrtilli, C. ledi, and C. fraudatrix) were collected in Finland, Sweden, Norway, Poland, Czech Republic, Bulgaria, and different regions of Russia (Figure 1, Tables 1 and S1). Entire specimens or the head and thorax part of individual Cacopsylla specimens were used for DNA extraction using DNeasy Blood and Tissue Kit and QIAamp DNA Investigator Kit (Qiagen, Inc. Valencia, CA, USA) following the manufacturer's protocols. Samples were processed at the Department of Biology of the 
University of Turku (Turku, Finland) and at the Department of Karyosystematics of the

Zoological Institute of the Russian Academy of Sciences (Saint-Petersburg, Russia).

Table 1. Sampling localities.

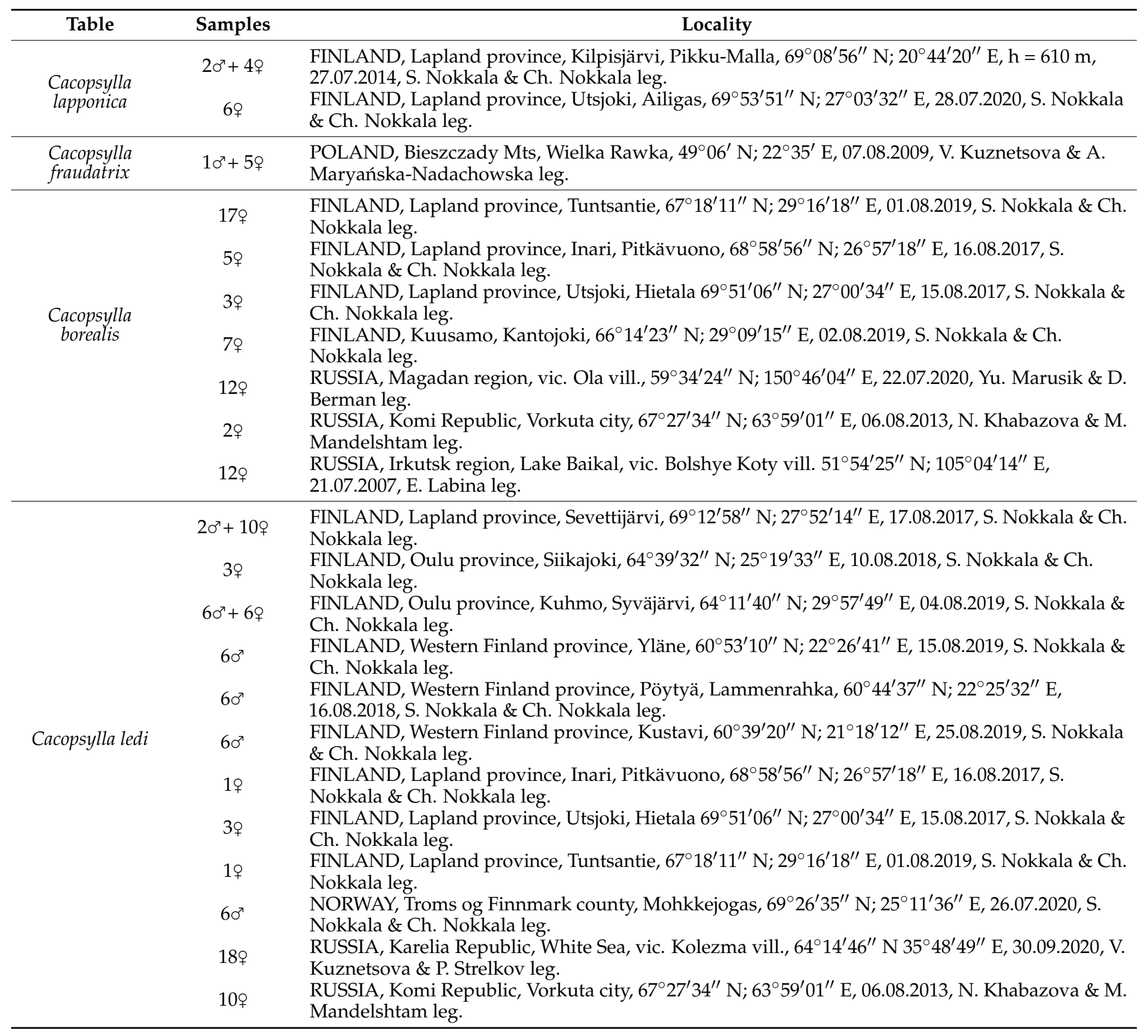


Table 1. Cont.

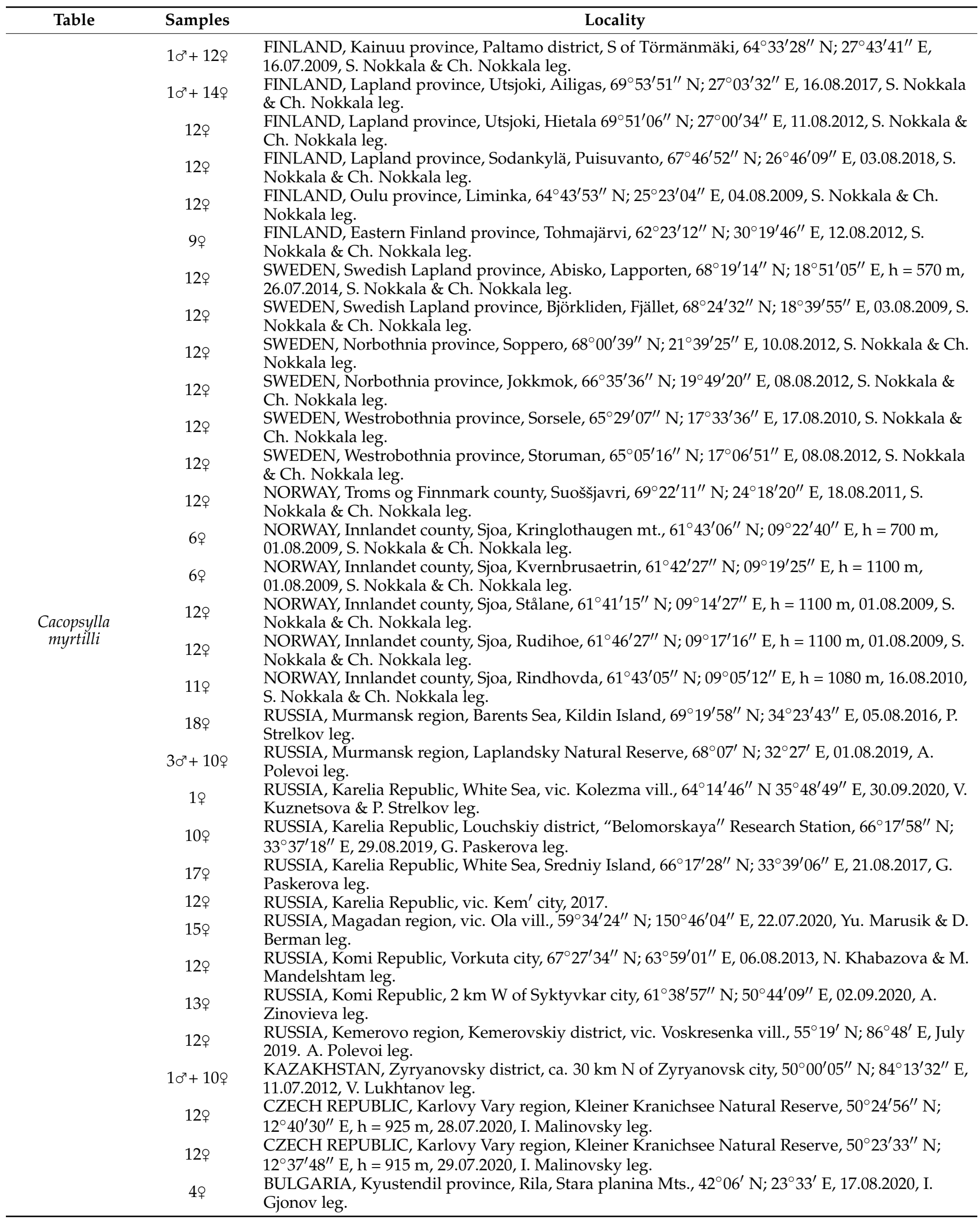




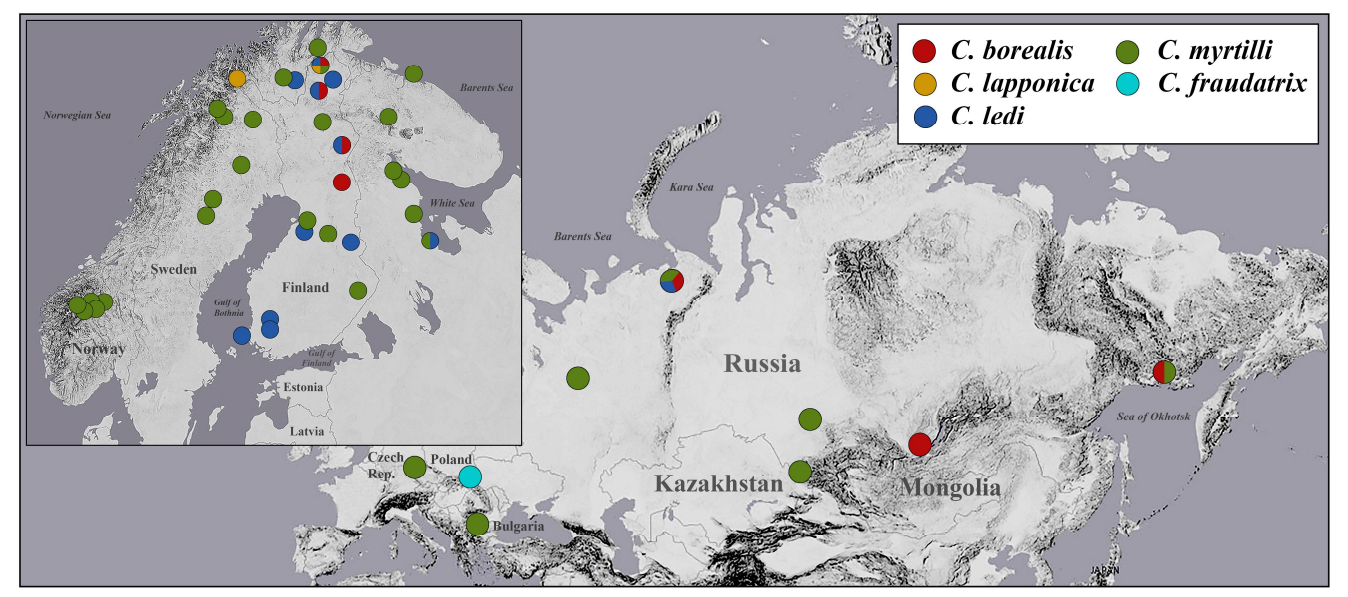

Figure 1. Map showing sampling localities of the analyzed specimens of Cacopsylla.

We screened all host specimens for Wolbachia infection by amplifying two genes, Wolbachia surface protein ( $w s p$ ) and $16 S$ ribosomal RNA, commonly used as markers to detect the presence of the bacteria. We used Wolbachia-specific primer pairs, wsp81F/wsp691R [50] and W-Specf/W-Specr [51], amplifying $550 \mathrm{bp}$ fragment of the wsp gene and $\sim 440 \mathrm{bp}$ fragment of the 16S RNA gene (actual fragment sizes depended on the individual Wolbachia strain), respectively. PCR reactions were carried out in $20 \mu \mathrm{L}$ volume $(1 \times$ PCR buffer, $2.0 \mathrm{mM} \mathrm{MgCl} 2,200 \mu \mathrm{M}$ dNTP each, $0.5 \mu \mathrm{M}$ of forward and reverse primers, $0.5 \mathrm{U}$ DreamTaq DNA Polymerase (ThermoFisher Scientific, Waltham, MA, USA), and $1 \mu \mathrm{L}$ (ca. $50 \mathrm{ng}$ ) of template DNA) using the following thermal profile: initial $5 \mathrm{~min}$ denaturation at $95{ }^{\circ} \mathrm{C}$ followed by 40 cycles of $30 \mathrm{~s}$ denaturation at $95^{\circ} \mathrm{C}, 1 \mathrm{~min}$ annealing at $45.5^{\circ} \mathrm{C}(w s p) / 49^{\circ} \mathrm{C}$ (16S), $45 \mathrm{~s}$ extension at $72{ }^{\circ} \mathrm{C}$ with a final extension at $72{ }^{\circ} \mathrm{C}$ for $2 \mathrm{~min}$. Each PCR reaction contained negative (PCR mix with $\mathrm{ddH}_{2} \mathrm{O}$ instead of DNA sample) and positive (genomic DNA of a Wolbachia-infected Cacopsylla specimen with already obtained wsp gene PCR product) controls. To ascertain the presence/absence of Wolbachia, each PCR product was checked on $1 \%$ standard agarose gel supplemented with $0.005 \%$ Midori Green Advance DNA stain (Nippon Genetics, Tokyo, Japan). After electrophoresis, the gels were inspected and photographed using GelDocEZ Imager (BioRad, Hercules, CA, USA). If a specimen was negative for one gene while positive for the other one, PCR was repeated in order to avoid the technical errors. Samples sufficiently yielding a product of the expected size for wsp and/or 16S RNA genes were scored as positive for Wolbachia; otherwise, they were scored as negative.

PCR products were purified using QIAquick PCR Purfication Kit (Qiagen, Inc. Valencia, CA, USA) or enzymes FastAP and ExoI (Thermofisher, Waltham, MA, USA) and sent to Macrogen Europe (Amsterdam, the Netherlands) or Evrogen (Moscow, Russia) for sequencing. Obtained sequences were deposited in GenBank under the accession numbers MZ684102-MZ684135.

\subsection{Molecular Data Analysis}

The sequences were edited and aligned using Geneious 8.1.6 [52] and BioEdit 7.0.3 [53] software. The BLAST algorithm implemented in NCBI (https:/ /blast.ncbi.nlm.nih.gov, (accessed on 20 August 2021) was used to search for sequence similarities in GenBank database with known DNA (BLASTN) sequences. We mined 68 sequences with highest percentage identity match, which we included in the phylogenetic analysis. To estimate phylogenetic relationships among Wolbachia alleles, a Bayesian approach was used. The analysis was performed using the MrBayes v.3.2.6 software [54] with the nucleotide substitution model GTR $+\mathrm{G}+\mathrm{I}$ as suggested by jModelTest v.2.1.7 [55]. Two independent MCMC runs of 10 million generations, with four simultaneous chains (one cold and three heated) for each analysis, were performed. The sampling of trees and parameters was set to every 1000 generations. The first $10 \%$ of trees were discarded as burn-in prior to computing a 
consensus phylogeny and posterior probabilities. The consensus of the obtained trees was visualized using FigTree 1.3.1 (http:/ / tree.bio.ed.ac.uk/software/figtree/ , (accessed on 20 August 2021). TRACER, v.1.6 was used for summarizing the results of the Bayesian phylogenetic analysis (http:/ / beast.bio.ed.ac.uk/Tracer, (accessed on 20 August 2021).

\subsection{Sample Karyotyping}

For Cacopsylla specimens collected in alcohol, a novel approach was developed that allows both chromosomal and molecular analyses of the same individual [44]. An individual was dissected and the abdomen was immersed in 3:1 Carnoy fixative overnight while both head and thorax remained in alcohol for subsequent DNA extraction, PCR, and sequencing. Chromosomal preparations were made, stained, and photographed following the method described earlier [44-47].

\section{Results}

\subsection{PCR Screening and Geographical Pattern of Wolbachia Incidence}

A total of 526 specimens belonging to five Cacopsylla species were screened for the presence of Wolbachia infection. Of these, 414 specimens were tested for both wsp and $16 S$ genes, 67 specimens were tested for $16 S$ gene only, 45 specimens were tested for wsp gene only. In general, screening for wsp and $16 S$ genes has shown similar patterns of infection. Only 16 specimens out of 414 ones (3.9\%) tested for two genes demonstrated dissimilar results, i.e., were positive for one gene, but negative for another gene (see Table S1).

Cacopsylla lapponica Nokkala et Nokkala, 2019

This is a rare, bisexually reproducing diploid species distributed in northern Fennoscandia at high altitudes above forest zone. The species has a karyotype $2 n=24+X X / X(0)$ (female/male) like most species of the genus Cacopsylla and the superfamily Psylloidea as a whole [47].

A total of 12 specimens ( 2 males and 10 females) from two geographically adjacent populations from northern Finland were studied (Figure 2a). Wolbachia screening for both wsp and $16 S$ genes demonstrated similar results, with only one exception. Sample CLAPP_f2 from Utsjoki, Ailigas was positive for $16 S$ gene, but negative for ws $p$ gene. Wolbachia infection was predominant in both populations. In total, 10 specimens (two males and eight females) were scored positive for Wolbachia infection (prevalence: 83.33\% [51.59-97.91\%]*).

* Here and further, values in square brackets are confidential interval.

Cacopsylla fraudatrix Labina et Kuznetsova, 2012

This is a bisexually reproducing diploid species, restricted in distribution to Bieszczady Mountains (Poland). The species has $2 n=24+X X / X(0)$ (female/male). $C$. fraudatrix thus shares the most commonly encountered karyotype in the genus Cacapsylla and in the superfamily Psylloidea as a whole [49].

A total of six specimens (one male and five females) from Bieszczady population were studied (Figure 2b). Of these, four specimens (one male and three females) were screened for both wsp and $16 S$ genes; two specimens (females) were screened for wsp gene only. In total, four specimens (females) were scored positive for Wolbachia infection (prevalence: $66.67 \%$ [22.28-95.67\%]).

Cacopsylla borealis Nokkala et Nokkala, 2019

This is a relatively common and widespread Palaearctic species, distributed from northern Fennoscandia in the west to Magadan in the east. C. borealis is a pentaploid species with $2 n=5 x=60+X X X X$ and apomictic parthenogenetic reproduction. No males have been recorded in C. borealis [47].

A total of 58 specimens (females) from seven geographically distinct populations (northern/central Finland and Russia (Vorkuta, Baikal Lake, and Magadan)) were studied for both $w s p$ and $16 S$ genes (Figure 2c). Wolbachia screening demonstrated similar results except for two samples from Utsjoki (Finland), which were positive for $16 S$ gene but negative for wsp gene. Wolbachia screening suggested $100 \%$ infection rate in the Vorkuta 
(Russia) population and a moderate infection rate in the population from Heitala (Finland). The other five populations were found to be Wolbachia-free. In total, nine specimens were scored positive for Wolbachia infection (prevalence: 15.52\% [7.35-27.42\%]).

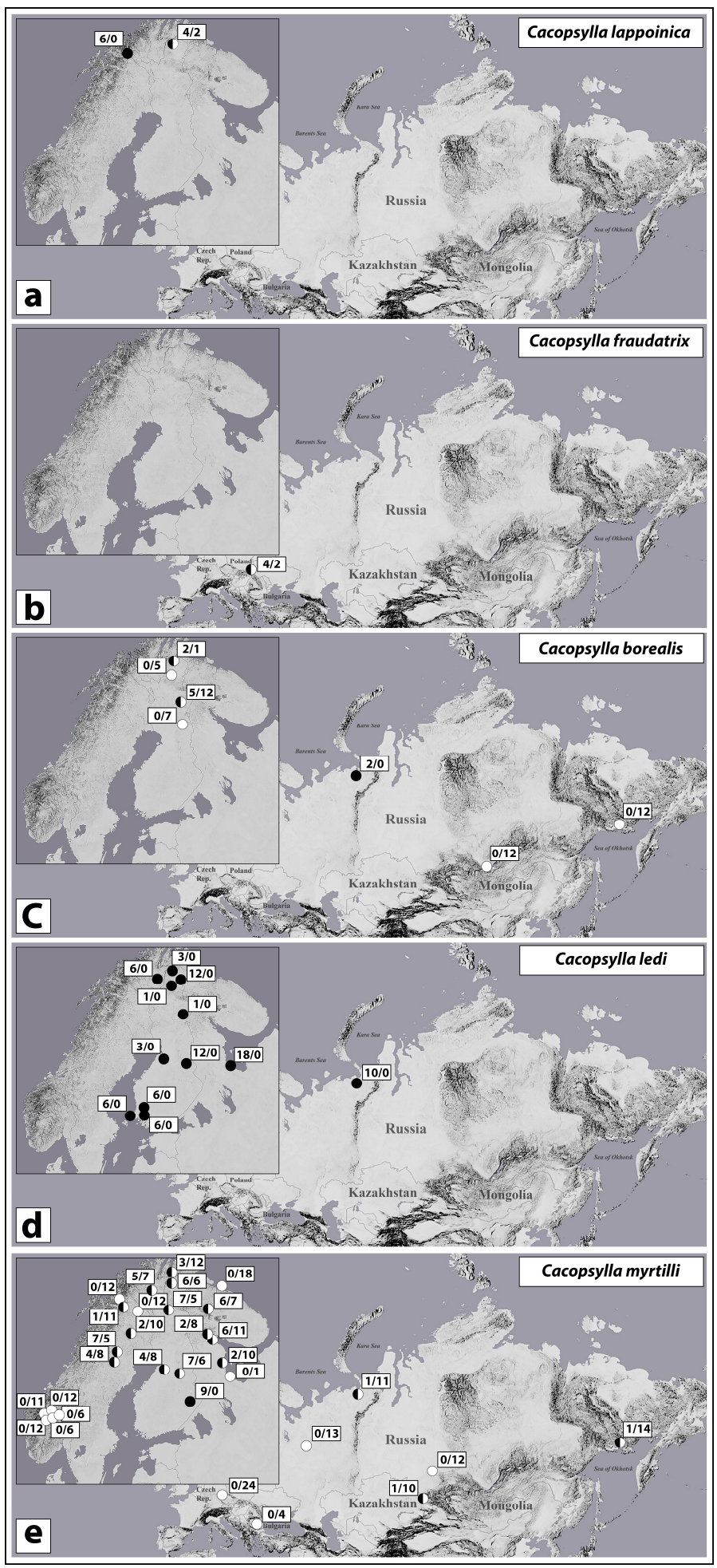

Figure 2. Distribution of Wolbachia infection in five Cacopsylla species (a-e). White circles indicate uninfected populations; black circles indicate completely infected populations; black-and-white circles indicate mixed populations comprising both infected and uninfected specimens. Numbers at circles indicate proportion of infected specimens (before slash) to uninfected specimens (after slash) in each population. 


\section{Cacopsylla ledi (Flor, 1861)}

This species is widely distributed throughout Fennoscandia, Central Europe, and Russia and occasionally forms sympatric populations with C. borealis. Its habitats are restricted to the temperate and alpine zones. The species is triploid $(2 n=3 x=36+X X X)$ and reproduces through apomictic parthenogenesis, while infrequent functional males with $2 n=24+X(0)$ can be found in some populations. In populations with rare males, infrequent diploid females with $2 \mathrm{n}=24+\mathrm{XX}$ also exist among the triploids [45].

A total of 84 specimens ( 52 females and 32 males) from 12 populations from Fennoscandia and northern Russia (Vorkuta) were studied (Figure 2d). Of these, 45 specimens were screened for both wsp and $16 S$ genes, 33 specimens were tested for $16 S$ gene only, and 6 specimens were tested for $w s p$ gene only. Two females from White Sea, Russia (CLKZ_f1 and CLKZ_f8) and one male from Finnmark, Norway were positive for $16 S$ gene and negative for $w s p$ gene. One specimen from Utsjoki, Finland (CLUH_f3) was positive for wsp gene but negative for $16 S$ gene. In total, all 84 specimens were scored positive for Wolbachia infection (prevalence: 100\% [95.7-100\%]).

Cacopsylla myrtilli (Wagner, 1947)

This species is widely distributed throughout the Palaearctic, while its distribution also shows a shift towards the north and/or high altitudes. As in C. ledi, females of this species are usually triploid $(2 n=3 x=36+X X X)$ and reproduce through apomictic parthenogenesis, while rare diploids also exist. Infrequent, mainly nonfunctional, but also functional, males can be found in some populations [44,45].

A total of 366 specimens (6 males and 360 females) from 32 geographically distinct populations (Fennoscandia; Czech Republic; Bulgaria; Kazakhstan; and north, central, and east Russia) were studied (Figure 2e). Of these, 295 specimens were screened for both wsp and $16 S$ genes, 34 specimens were tested for $16 S$ gene only, and 37 specimens were tested for $w s p$ gene only. Eight specimens were positive for $16 S$ gene and negative for $w s p$ gene. In total, 84 specimens out of 366 studied ones (including one of the six males) were scored positive for Wolbachia infection (prevalence: 22.95\% [18.74-27.61\%]).

PCR screening revealed a complicated geographical pattern of Wolbachia incidence in this species. Large geographical areas, including southern and central Europe (Bulgaria, Czech Republic), southern and northwestern Norway, northern Sweden, northern Russia (Kildin Island (Barents Sea), Syktyvkar), and Siberia (Kemerovo) were Wolbachia-free. A low infection rates were found in Kazakhstan, Vorkuta (northern Russia), and Magadan (Russian Far East). A moderate infection rate was detected in the majority of populations from central and northern Fennoscandia. A single, completely infected population, Tohmajärvi, was found in Central Finland.

\subsection{Wolbachia Alleles Identified in Cacopsylla Species}

A $541 \mathrm{bp}$ fragment of the Wolbachia wsp gene was sequenced for 34 infected specimens of five host Cacopsylla species, C. borealis, C. lapponica, C. ledi, C. myrtilli, and C. fraudatrix (Table 2).

Sequencing revealed three wsp alleles among samples from four host species, C. borealis, C. lapponica, C. ledi, and C. myrtilli. In C. fraudatrix, at least two alternative Wolbachia alleles were found, however the presence of heteroplasmy, indicated by double peaks on the chromatograms, does not allow unambiguously assigning sequences to a particular wsp allele (for the identified alleles, see Table 3). 
Table 2. List of specimens sequenced for Wolbachia wsp gene.

\begin{tabular}{|c|c|c|c|c|c|}
\hline Host Taxon & Sample ID & $\begin{array}{c}\text { GB } \\
\text { Accession No. }\end{array}$ & Sex & Allele & Locality \\
\hline Cacopsylla lapponica & CLAPP-M_f2 & MZ684116 & q & wMyr01 & FINLAND, Kilpisjärvi, $69^{\circ} 08^{\prime} 56^{\prime \prime} \mathrm{N} ; 20^{\circ} 44^{\prime} 20^{\prime \prime} \mathrm{E}$ \\
\hline Cacopsylla lapponica & $\begin{array}{l}\text { CLAPP- } \\
\text { M_m3 }\end{array}$ & MZ684117 & q & wMyr01 & FINLAND, Kilpisjärvi, $69^{\circ} 08^{\prime} 56^{\prime \prime} \mathrm{N} ; 20^{\circ} 44^{\prime} 20^{\prime \prime} \mathrm{E}$ \\
\hline Cacopsylla lapponica & CLAPP-M_f4 & MZ684118 & $\sigma^{7}$ & wMyr01 & FINLAND, Kilpisjärvi, $69^{\circ} 08^{\prime} 56^{\prime \prime} \mathrm{N} ; 20^{\circ} 44^{\prime} 20^{\prime \prime} \mathrm{E}$ \\
\hline Cacopsylla fraudatrix & CFR_f5 & MZ684132 & q & * & POLAND, Bieszczady $49^{\circ} 06^{\prime} \mathrm{N} ; 22^{\circ} 35^{\prime} \mathrm{E}$ \\
\hline Cacopsylla fraudatrix & CFR_f7 & MZ684133 & 우 & * & POLAND, Bieszczady $49^{\circ} 06^{\prime} \mathrm{N} ; 22^{\circ} 35^{\prime} \mathrm{E}$ \\
\hline Cacopsylla fraudatrix & CFR_f8 & MZ684134 & 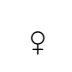 & $\begin{array}{l}\text { wFr01 } \\
w F r 02\end{array}$ & POLAND, Bieszczady $49^{\circ} 06^{\prime} \mathrm{N} ; 22^{\circ} 35^{\prime} \mathrm{E}$ \\
\hline Cacopsylla fraudatrix & CFR_f9 & MZ684135 & $q$ & * & POLAND, Bieszczady $49^{\circ} 06^{\prime} \mathrm{N} ; 22^{\circ} 35^{\prime} \mathrm{E}$ \\
\hline Cacopsylla borealis & CBST_f3 & MZ684111 & 우 & wMyr01 & FINLAND, Tuntsantie, $67^{\circ} 18^{\prime} 11^{\prime \prime} \mathrm{N} ; 2^{\circ} 16^{\prime} 18^{\prime \prime} \mathrm{E}$ \\
\hline Cacopsylla borealis & CBST_f4 & MZ684112 & 우 & wMyr01 & FINLAND, Tuntsantie, $67^{\circ} 18^{\prime} 11^{\prime \prime} \mathrm{N} ; 29^{\circ} 16^{\prime} 18^{\prime \prime} \mathrm{E}$ \\
\hline Cacopsylla borealis & CBST_f5 & MZ684113 & q & wMyr01 & FINLAND, Tuntsantie, $67^{\circ} 18^{\prime} 11^{\prime \prime} \mathrm{N} ; 2^{\circ} 16^{\prime} 18^{\prime \prime} \mathrm{E}$ \\
\hline Cacopsylla borealis & CV_f11 & MZ684114 & 우 & wMyr02 & RUSSIA, Vorkuta $67^{\circ} 27^{\prime} 34^{\prime \prime} \mathrm{N} ; 63^{\circ} 59^{\prime} 01^{\prime \prime} \mathrm{E}$ \\
\hline Cacopsylla borealis & CV_f1 & MZ684115 & 우 & wLed & RUSSIA, Vorkuta $67^{\circ} 27^{\prime} 34^{\prime \prime} \mathrm{N} ; 63^{\circ} 59^{\prime} 01^{\prime \prime} \mathrm{E}$ \\
\hline Cacopsylla ledi & CacoS1_f1D & MZ684119 & 운 & wMyr01 & FINLAND, Sevettijärvi, $69^{\circ} 12^{\prime} 58^{\prime \prime} \mathrm{N} ; 27^{\circ} 52^{\prime} 14^{\prime \prime} \mathrm{E}$ \\
\hline Cacopsylla ledi & CacoS1_f16D & MZ684120 & q & wMyr01 & FINLAND, Sevettijärvi, $69^{\circ} 12^{\prime} 58^{\prime \prime} \mathrm{N} ; 27^{\circ} 52^{\prime} 14^{\prime \prime} \mathrm{E}$ \\
\hline Cacopsylla ledi & CacoS1_f19T & MZ684121 & 우 & wMyr01 & FINLAND, Sevettijärvi, $69^{\circ} 12^{\prime} 58^{\prime \prime} \mathrm{N} ; 27^{\circ} 52^{\prime} 14^{\prime \prime} \mathrm{E}$ \\
\hline Cacopsylla ledi & CacoS1_f23T & MZ684122 & q & wMyr01 & FINLAND, Sevettijärvi, $69^{\circ} 12^{\prime} 58^{\prime \prime} N ; 27^{\circ} 52^{\prime} 14^{\prime \prime} \mathrm{E}$ \\
\hline Cacopsylla ledi & CacoS1_m2 & MZ684123 & $\sigma^{7}$ & wMyr01 & FINLAND, Sevettijärvi, $69^{\circ} 12^{\prime} 58^{\prime \prime} \mathrm{N} ; 27^{\circ} 52^{\prime} 14^{\prime \prime} \mathrm{E}$ \\
\hline Cacopsylla ledi & CacoS1_m3 & MZ684124 & $\sigma^{7}$ & wMyr01 & FINLAND, Sevettijärvi, $69^{\circ} 12^{\prime} 58^{\prime \prime} N ; 27^{\circ} 52^{\prime} 14^{\prime \prime} \mathrm{E}$ \\
\hline Cacopsylla ledi & CLKH_f2D & MZ684125 & q & wMyr01 & FINLAND, Kuhmo, $64^{\circ} 11^{\prime} 40^{\prime \prime} \mathrm{N} ; 29^{\circ} 57^{\prime} 49^{\prime \prime} \mathrm{E}$ \\
\hline Cacopsylla ledi & CLKH_f3D & MZ684126 & q & wMyr01 & FINLAND, Kuhmo, $64^{\circ} 11^{\prime} 40^{\prime \prime} \mathrm{N} ; 2^{\circ} 57^{\prime} 49^{\prime \prime} \mathrm{E}$ \\
\hline Cacopsylla ledi & CLKH_m30 & MZ684127 & $\sigma^{7}$ & wMyr01 & FINLAND, Kuhmo, $64^{\circ} 11^{\prime} 40^{\prime \prime} \mathrm{N} ; 29^{\circ} 57^{\prime} 49^{\prime \prime} \mathrm{E}$ \\
\hline Cacopsylla ledi & CLKH_m34 & MZ684128 & $0^{x}$ & wMyr01 & FINLAND, Kuhmo, $64^{\circ} 11^{\prime} 40^{\prime \prime} \mathrm{N} ; 2^{\circ} 57^{\prime} 49^{\prime \prime} \mathrm{E}$ \\
\hline Cacopsylla ledi & CLV_f2 & MZ684129 & q & wLed & RUSSIA, Vorkuta $67^{\circ} 27^{\prime} 34^{\prime \prime} \mathrm{N} ; 63^{\circ} 59^{\prime} 01^{\prime \prime} \mathrm{E}$ \\
\hline Cacopsylla ledi & CLV_f3 & MZ684130 & q & wLed & RUSSIA, Vorkuta $67^{\circ} 27^{\prime} 34^{\prime \prime} \mathrm{N} ; 63^{\circ} 59^{\prime} 01^{\prime \prime} \mathrm{E}$ \\
\hline Cacopsylla ledi & CLV_f6 & MZ684131 & q & wLed & RUSSIA, Vorkuta $67^{\circ} 27^{\prime} 34^{\prime \prime} \mathrm{N} ; 63^{\circ} 59^{\prime} 01^{\prime \prime} \mathrm{E}$ \\
\hline Cacopsylla myrtilli & CMFIJUO_f08 & MZ684102 & o & wMyr01 & NORWAY, Suoššjavri, $69^{\circ} 22^{\prime} 11^{\prime \prime} \mathrm{N} ; 24^{\circ} 18^{\prime} 20^{\prime \prime} \mathrm{E}$ \\
\hline Cacopsylla myrtilli & CMFI_f14 & MZ684103 & q & wMyr01 & NORWAY, Suoššjavri, $69^{\circ} 22^{\prime} 11^{\prime \prime} \mathrm{N} ; 24^{\circ} 18^{\prime} 20^{\prime \prime} \mathrm{E}$ \\
\hline Cacopsylla myrtilli & CMPAL_m16 & MZ684104 & $\sigma^{2}$ & wMyr01 & FINLAND, Paltamo, $64^{\circ} 33^{\prime} 28^{\prime \prime} \mathrm{N} ; 27^{\circ} 43^{\prime} 41^{\prime \prime} \mathrm{E}$ \\
\hline Cacopsylla myrtilli & CMST_f8 & MZ684105 & $q$ & wMyr01 & SWEDEN, Storuman, $65^{\circ} 05^{\prime} 16^{\prime \prime} \mathrm{N} ; 17^{\circ} 06^{\prime} 51^{\prime \prime} \mathrm{E}$ \\
\hline Cacopsylla myrtilli & CMST_f11 & MZ684106 & q & wMyr01 & SWEDEN, Storuman, $65^{\circ} 05^{\prime} 16^{\prime \prime} \mathrm{N} ; 17^{\circ} 06^{\prime} 51^{\prime \prime} \mathrm{E}$ \\
\hline Cacopsylla myrtilli & CMJO_f22 & MZ684107 & 우 & wMyr01 & SWEDEN, Jokkmok, $66^{\circ} 35^{\prime} 36^{\prime \prime} \mathrm{N} ; 1^{\circ} 49^{\prime} 20^{\prime \prime} \mathrm{E}$ \\
\hline Cacopsylla myrtilli & CMV_f22 & MZ684108 & q & wMyr01 & RUSSIA, Vorkuta $67^{\circ} 27^{\prime} 34^{\prime \prime} \mathrm{N} ; 63^{\circ} 59^{\prime} 01^{\prime \prime} \mathrm{E}$ \\
\hline Cacopsylla myrtilli & CM6.10 & MZ684109 & 우 & wMyr01 & $\begin{array}{l}\text { KAZAKHSTAN, Zyryanovsk, } 50^{\circ} 00^{\prime} 05^{\prime \prime} \mathrm{N} ; \\
84^{\circ} 13^{\prime} 32^{\prime \prime} \mathrm{E}\end{array}$ \\
\hline Cacopsylla myrtilli & CMMAG_f10 & MZ684110 & q & wMyr02 & RUSSIA, Magadan $59^{\circ} 34^{\prime} 24^{\prime \prime} \mathrm{N} ; 150^{\circ} 46^{\prime} 04^{\prime \prime} \mathrm{E}$ \\
\hline
\end{tabular}

The asterisk $(*)$ indicates samples that cannot be attributed to any Wolbachia allele due to presence of more than one heterogeneity in wsp gene sequences.

Table 3. Variable sites of the studied Wolbachia wsp gene fragment among the 34 samples sequenced.

\begin{tabular}{ccccc}
\hline \multirow{2}{*}{ Allele } & \multicolumn{4}{c}{ Nucleotide Position } \\
\cline { 2 - 5 } & $\mathbf{3 6 0}$ & $\mathbf{4 9 5}$ & $\mathbf{4 9 8}$ & $\mathbf{4 9 9}$ \\
\hline$w$ Myr01 & $\mathrm{C}$ & $\mathrm{C}$ & $\mathrm{A}$ & $\mathrm{G}$ \\
$w$ Myr02 & $\mathrm{C}$ & $\mathrm{C}$ & $\mathrm{G}$ & $\mathrm{G}$ \\
$w$ Led & $\mathrm{C}$ & $\mathrm{C}$ & $\mathrm{A}$ & $\mathbf{C}$ \\
$w$ Fr01 & $\mathrm{C}$ & $\mathbf{A}$ & $\mathrm{A}$ & $\mathrm{G}$ \\
$w$ Fr02 & $\mathbf{A}$ & $\mathbf{A}$ & $\mathrm{A}$ & $\mathrm{G}$ \\
\hline
\end{tabular}

BLAST search ascertained that the obtained sequences were unique, showing that they belonged to the supergroup B (grouping according to [56]). Comparison with Wolbachia sequences deposited in the public databases GenBank (http:/ /www.ncbi.nlm.nih.gov, (accessed on 20 August 2021) and PubMLST-Wolbachia (https:/ / pubmlst.org/organisms / wolbachia-spp, (accessed on 01 September 2021) revealed that Wolbachia alleles isolated 
from Cacopsylla hosts were most similar to wsp allele 639 found in lycaenid butterflies [57,58], differing from the latter in 3-4 nucleotide substitutions only. Most of the specimens analyzed (24 out of 30 ) of the host species C. myrtilli, C. borealis, C. lapponica, and C. ledi harbored the major wsp allele, wMyr01 (allele names follow the earlier accepted abbreviation style [50,59]). Most likely, this allele is also present in C. fraudatrix specimens CFR_f5, CFR_f7, and CFR_f9. However, cloning procedure is required to confirm this suggestion. The only Wolbachia-positive specimen of C. myrtilli (CMMAG_f10) from Magadan (out of the 15 specimens analyzed) differed from the most common and widespread allele $w$ Myr01 in one nucleotide substitution (transition $A=>G$ ) at site 498. The same substitution was found in one $C$. borealis specimen (CV_f11) from Vorkuta. This allele was designated as $w$ Myr02. The other specimen of $C$. borealis from Vorkuta (CBV_f1) (out of the two specimens analyzed) possessed a nucleotide substitution (transversion $G=>C$ ) at site 499 . The same transversion was found in three C. ledi specimens from Vorkuta (CLV_f2, CLV_f3, CLV_f6). This allele was designated as wLed. C. fraudatrix specimen CFR_f8 differed from all other samples by a nucleotide substitution $C=>A$ at site 495 . In addition, it displayed intra-individual polymorphism at site 360, indicating presence of two alleles not yet found in other Cacopsylla species and designated here as $w \mathrm{Fr} 01$ and $w \mathrm{Fr} 02$, respectively. Two polymorphic positions (C/A at sites 360 and 495) found in C. fraudatrix samples CFR_f5, CFR_f7, and CFR_f9 did not allow unambiguously assigning sequences to any ws $p$ allele. Most likely, these specimens were infected by two or three Wolbachia alleles (wMyr01, $w$ Fr02, and/or wFr01). Geographical distribution of revealed Wolbachia alleles is shown in Figure 3.

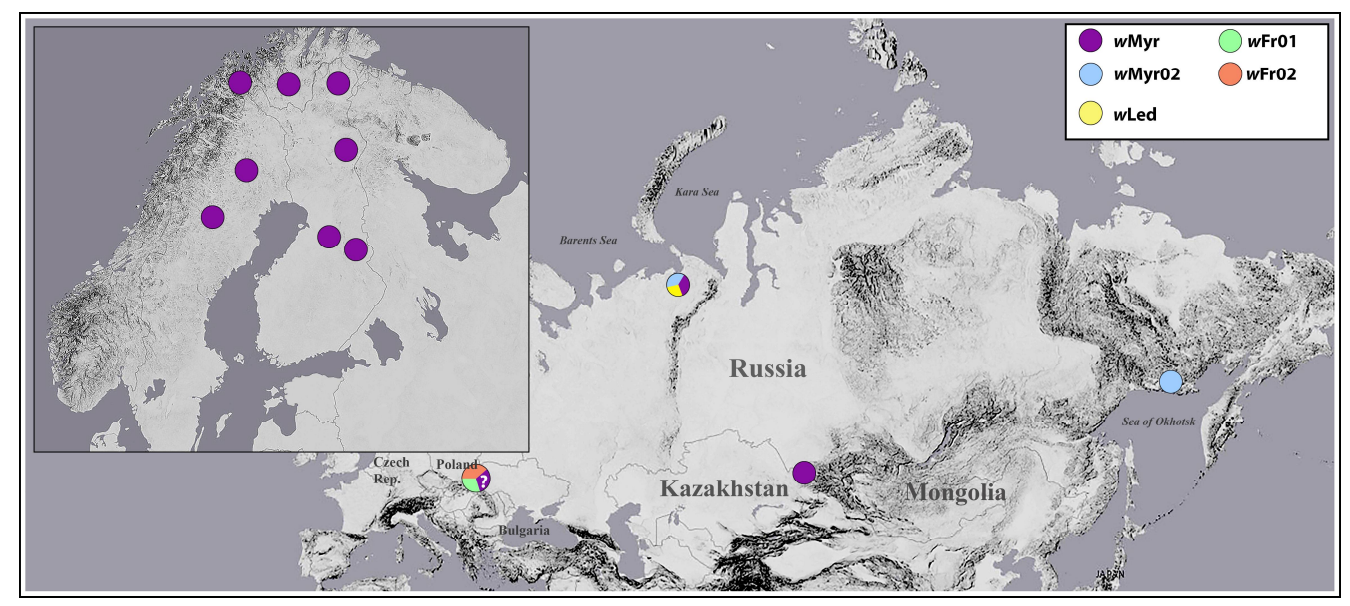

Figure 3. Map showing geographical distribution of revealed Wolbachia wsp alleles.

\subsection{Phylogenetic Inferences}

We used the 68 most similar Wolbachia wsp sequences with known host species mined from GenBank to infer the Wolbachia phylogeny. Wolbachia wsp sequence of nematode Brugia malayi (Brug, 1927) (GenBank accession number AY527202) belonging to the supergroup $\mathrm{D}$ was included in our analysis as an outgroup to root the phylogeny. Bayesian analysis recovered two clades (Figure 4 ) that received high (clade II, BS =1) and moderate (clade I, BS = 0.89) support. All wsp sequences of five host Cacopsylla species obtained in the present study clustered within clade I together with Wolbachia strains from different insect orders (Lepidoptera, Plecoptera, Orthoptera, Hemiptera, Hymenoptera, Diptera) and acariform mites (Trombidiformes). Maximum p-distances between samples constituting clade I were as high as $2.92 \%$. The second clade comprised Wolbachia strains found in Coleoptera, Hymenoptera, Hemiptera, Lepidoptera, Diptera (Insecta), and Trombidiformes (Arachnida). Genetic distances between Wolbachia strains of the clade II and those found in Cacopsylla ranged from $5.29 \%$ to $7.48 \%$. 


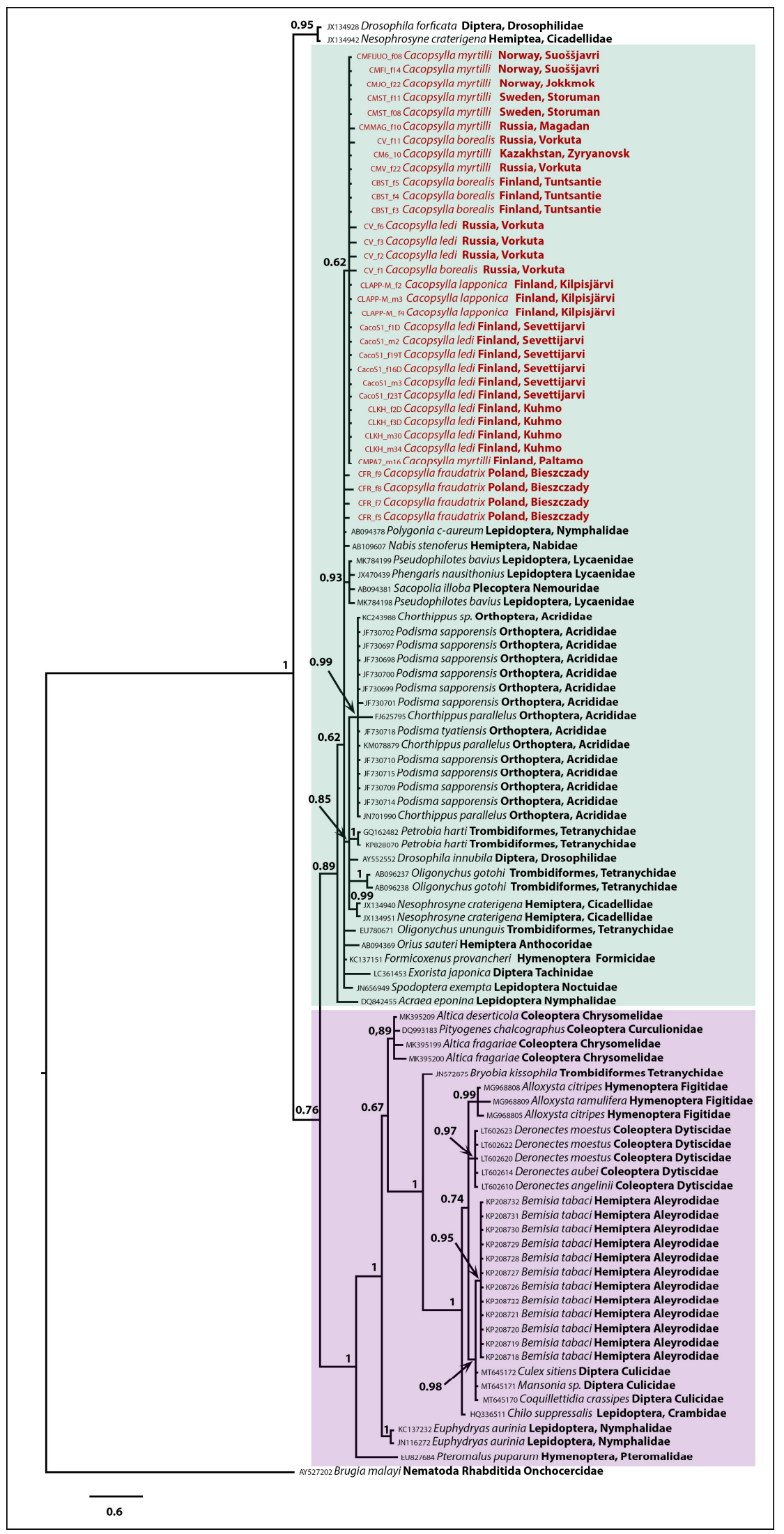

Figure 4. The Bayesian tree of analyzed Wolbachia samples. Numbers at nodes indicate Bayesian posterior probability. Scale bar $=0.6$ substitutions. Revealed Wolbachia clusters are highlighted in violet and green. 


\section{Discussion}

\subsection{Wolbachia Infection in Hemiptera}

Numerous reports on Wolbachia in different arthropod taxa have clearly shown that the infection is widespread across this group of animals. However, recent studies have suggested that, to date, less than $1 \%$ of all existing Wolbachia strains have been characterized [60]. The most comprehensive molecular data on Wolbachia sequences and allelic profiles can be found on the PubMLST-Wolbachia database, available at http: //pubmlst.org/wolbachia/, (accessed on 01 September 2021) [61]. The data representation in the database is strongly biased to five insect orders (Lepidoptera, Coleoptera, Hemiptera, Hymenoptera, and Diptera), which account for $79 \%$ of the total Wolbachia strains deposited. Despite the fact that Hemiptera is one of the most represented orders $(297$ (14.7\%) out of over 2000 Wolbachia strains deposited in PubMLST-Wolbachia (by September 2021) belong to Hemiptera), most hemipteran families and genera have not yet been examined. Moreover, the majority of the Wolbachia strains were characterized in Hemiptera species inhabiting Asia, Africa, South America, and Australasia, while only one record comes from Europe. For the family Psyllidae, only 26 Wolbachia strains are reported in PubMLST-Wolbachia (none of these belong to the genus Cacopsylla) - eight were isolated from Diaphorina citri and one was isolated from Heteropsylla sp., while for 17 isolated strains the host genus and the host species were not determined. Nevertheless, a number of studies dedicated to Cacopsylla associations with various bacterial endosymbionts [62,63], including Wolbachia [64,65], have been published over the past decade. It should be noted, that most of the published investigations contain data on a single (or very low number) of species, in which usually only a few individuals were tested. Testing only a small number of specimens and/or screening single Wolbachia-specific genes could obscure our understanding of the presence and actual rate of Wolbachia infection, and, therefore, the impact of Wolbachia on biology and evolution of host species. Firstly, it significantly increases the possibility of occasionally picking uninfected specimens from a pool of infected and uninfected individuals, especially if prevalence rates are low. Low infection rate was reported, for instance, for fruit fly Bactocera dorsalis (Hendel, 1912) (Diptera: Tephritidae), where screening of 1500 individuals revealed infection frequencies ranging from $0 \%$ to $3 \%$ [66]. Secondly, frequency of infection may vary significantly (from $0 \%$ to $100 \%$ ) between different populations of the same species, as it was shown for fruit flies [67], planthoppers [68], and for Cacopsylla in the present study. Thirdly, species might also be erroneously classified as uninfected due to low-titer infections that are not detected by common PCR screening or extremely weak/unsuccessful amplification if nucleotide substitutions in the regions targeted by Wolbachia-specific primers are present, resulting in a significant decrease of primer efficiency. Finally, some Wolbachia genes can be incorporated into the host nuclear genome, leading to false positive PCR results. Thus, in order to improve estimates of infection frequencies and more accurately assess the incidence of Wolbachia and its influence on host species, it is crucial to use several Wolbachia-specific molecular markers and to include a large-scale sampling dataset in the analysis.

\subsection{Patterns of Wolbachia Infection in Cacopsylla}

Our study is the first to report patterns and diversity of Wolbachia infection in five jumping plant-lice species of the genus Cacopsylla based on geographically wide sampling, using PCR assays for the Wolbachia-specific wsp and $16 S$ genes. In general, screening for wsp and $16 S$ genes has shown a similar pattern of infection in the studied species. Only 16 specimens (3.9\%) out of 414 tested for two genes demonstrated contradictory results, with 15 cases positive for $16 S$ gene and negative for wsp gene. We can assume that Wolbachia persists in these specimens at a low density and, thus, conventional PCR-screening does not detect infection if the used primers are not sensitive enough. Recent surveys have suggested that low-titer Wolbachia infection within arthropod hosts is more common than considered previously $[68,69]$. Alternatively, the absence of amplification using wsp primers 
can be explained by primer/template mismatch in the region targeted by Wolbachia-specific primers, leading to unsuccessful PCR amplification.

The studied Cacopsylla species displayed a complex pattern of Wolbachia infection. They included both infected and uninfected populations and different ws $p$ gene alleles, which corresponded to their geographical distribution. A total of five wsp alleles were revealed. The geographically widely distributed $w \mathrm{Myr} 01$ is shared by Wolbachia infecting C. myrtilli, C. borealis, C. lapponica, C. ledi, and, probably, C. fraudatrix (see Section 3.2. in Results). This suggests either common origin of the infection or the transmission of this allele between the species. Allele $w \mathrm{Myr} 02$ was encountered in C. myrtilli only, being found in two geographically distinct populations from Vorkuta and Magadan. Allele $w$ Led was encountered in C. ledi and C. borealis, being found only in Vorkuta populations. Thus, three alleles, $w \mathrm{Myr} 01, w \mathrm{Myr} 02$, and $w$ Led, sympatrically co-exist in Vorkuta. Alleles $w \mathrm{Fr} 01$ and $w \mathrm{Fr} 02$ were found only in $C$. fraudatrix, which was the only species showing intraindividual allele polymorphism, suggesting coinfection by genetically different Wolbachia. We can speculate that allele $w$ Fr01 first appeared as a result of a single substitution in allele $w$ Myr01; subsequently, substitution in allele $w$ Fr01 led to evolving $w \operatorname{Fr} 02$. The data obtained suggest that scenarios of Wolbachia infection in C. fraudatrix and other Cacopsylla species were different.

Wolbachia was predominant in diploid bisexual species C. lapponica and C. fraudatrix (infection rate $83 \%$ and $67 \%$, respectively) and totally infected triploid parthenogenetic species C. ledi. Unlike C. ledi, "female-only" pentaploid C. borealis demonstrated a very low rate of infection $(15 \%)$, with several Wolbachia-free populations. The most complicated pattern of Wolbachia incidence was observed in triploid parthenogenetic C. myrtilli. Different populations of this species showed either (1) total infection, (2) a moderate rate of infection, (3) a low rate of infection, or (4) absence of infection, respectively. Some Wolbachia-free populations were found to be surrounded by moderately infected populations, e.g., Soppero and Björkliden in northern Sweden, and Kildin Island in Russia. These populations were probably formed by Wolbachia-free founder specimens. A quite different scenario can be suggested to explain existence of vast Wolbachia-free areas encompassing southern Norway, central and southeastern Europe (Czech Republic, Bulgaria), the Polar Ural Mountains, and Siberia (Russia). We hypothesize that Cacopsylla species inhabiting these areas originated in Wolbachia-free refugia during the post-glacial period.

Phylogenetic analysis revealed a high rate of similarity between wsp sequences of five host Cacopsylla species, with Wolbachia strains infecting insect orders Lepidoptera, Plecoptera, Orthoptera, Hemiptera, Hymenoptera, Diptera, and acariform mites (Trombidiformes). Sharing similar Wolbachia alleles between Cacopsylla and members of other arthropods can be explained neither by common origin nor hybridization, with the most likely explanation being that it is a result of horizontal transfer. Particular Wolbachia strains can be transferred to phylogenetically distant arthropods either through shared parasitoids [70] or, in plant-sup feeders, through their saliva [71-73].

\section{Conclusions}

Our study is the first attempt of large-scale investigation aimed at a detailed analysis of presence, prevalence, geographical distribution, and molecular characterization of Wolbachia infection in the species-rich hemipteran genus Cacopsylla (Hemiptera, Psylloidea). The genus comprises species with different reproductive strategies (bisexual and parthenogenetic) and ploidy levels (diploids, triploids, and pentaploids). One of the well-known effects of Wolbachia is male killing, leading to a prevalence of females or complete elimination of males in the certain populations of the host species and a subsequent shift to parthenogenetic reproduction. We tested the assumption that a variety of reproductive strategies observed in distinct Cacopsylla species and the existence of "female-only" populations or populations heavily biased towards females are the consequences of Wolbachia infection. Our survey did not reveal significant differences in infection frequency between parthenogenetic and bisexual populations or between males and females within bisexual 
populations. We suggest that the evolution of various reproductive strategies in Cacopsylla is not attributable to an effect of Wolbachia and was probably driven by some other, most likely environmental factors, which have not yet been studied. At the same time, complicated phylogeographic patterns of Wolbachia infection were observed in the genus Cacopsylla. We found that Wolbachia infected all five studied Cacopsylla species, reflecting the significant role of the endosymbiont in their biology. We conclude that our survey in the context of complex temporal and spatial patterns of Wolbachia infection represents a potential model for future research and provides insights into the factors impacting Wolbachia and its interactions with psyllids and insects as a whole.

Supplementary Materials: The following are available online at https:/ / www.mdpi.com/article/10 .3390 /insects12100853/s1, Table S1: List of studied material.

Author Contributions: Project design, V.G.K.; conceptualization, N.A.S.; methodology, N.A.S., S.N., C.N. and V.G.K.; PCR screening and sequencing, S.N., C.N. and G.N.K.; molecular analysis, N.A.S. and G.N.K.; writing—original draft preparation, N.A.S. and V.G.K.; writing—review and editing, S.N and C.N.; figure preparation N.A.S. and G.N.K. All authors have read and agreed to the published version of the manuscript.

Funding: The financial support for this study was provided to N.A.S. and V.G.K. by the grant No. 1914-00202 from the Russian Science Foundation to the Zoological Institute of the Russian Academy of Sciences (molecular studies) and the state research project No. AAAA-A19-119020790106-0 (collecting the material).

Institutional Review Board Statement: Not applicable.

Acknowledgments: The authors are grateful to N. Khabazova, M. Mandelshtam, E. Labina, G. Paskerova, P. Strelkov, A. Maryańska-Nadachowska, Yu. Marusik, D. Berman, A. Polevoi, A. Zinovieva, V. Lukhtanov, I. Malinovsky, and I. Gjonov for their help in collecting material for the present study and to A. Gagarina for assistance in DNA extraction and PCR screening.

Conflicts of Interest: All authors declare no conflict of interest. The funders had no role in the design of the study; in the collection, analyses, or interpretation of data; in the writing of the manuscript, or in the decision to publish the results.

\section{References}

1. Ahmed, M.Z.; Araujo-Jnr, E.V.; Welch, J.J.; Kawahara, A.Y. Wolbachia in butterflies and moths: Geographic structure in infection frequency. Front. Zool. 2015, 12, 16. [CrossRef]

2. Hertig, M.; Wolbach, S.B. Studies on Rickettsia-like microorganisms in insects. J. Med. Res. 1924, 44, 329-374.

3. Hertig, M. The Rickettsia, Wolbachia pipientis (gen. et sp.n.) and associated inclusions of the Mosquito, Culex pipiens. Parasitology 1936, 28, 453-486. [CrossRef]

4. Hilgenboecker, K.; Hammerstein, P.; Schlattmann, P.; Telschow, A.; Werren, J.H. How many species are infected with Wolbachia? -A statistical analysis of current data. FEMS Microbiol. Lett. 2008, 281, 215-220. [CrossRef]

5. Werren, J.H.; Baldo, L.; Clark, M.E. Wolbachia: Master manipulators of invertebrate biology. Nat. Rev. Microbiol. 2008, 6, 741-751. [CrossRef] [PubMed]

6. Zug, R.; Hammerstein, P. Still a host of hosts for Wolbachia: Analysis of recent data suggests that $40 \%$ of terrestrial arthropod species are infected. PLoS ONE 2012, 7, e38544. [CrossRef] [PubMed]

7. Lefoulon, E.; Clark, T.; Borveto, F.; Perriat-Sanguinet, M.; Moulia, C.; Slatko, B.E.; Gavotte, L. Pseudoscorpion Wolbachia symbionts: Diversity and evidence for a new supergroup S. BMC Microbiol. 2020, 20, 188. [CrossRef] [PubMed]

8. Bandi, C.; Anderson, T.J.; Genchi, C.; Blaxter, M.L. Phylogeny of Wolbachia in filarial nematodes. Proc. R. Soc. Lond. B Biol. Sci. 1998, 265, 2407-2413. [CrossRef] [PubMed]

9. Casiraghi, M.; Bain, O.; Guerrero, R.; Martin, C.; Pocacqua, V.; Gardner, S.L.; Franceschi, A.; Bandi, C. Mapping the presence of Wolbachia pipientis on the phylogeny of filarial nematodes: Evidence for symbiont loss during evolution. Int. J. Parasitol. 2004, 34, 191-203. [CrossRef]

10. Lefoulon, E.; Bain, O.; Makepeace, B.L.; d'Haese, C.; Uni, S.; Martin, C.; Gavotte, L. Breakdown of coevolution between symbiotic bacteria Wolbachia and their filarial hosts. PeerJ 2016, 4, e1840. [CrossRef]

11. Brown, A.M.; Wasala, S.K.; Howe, D.K.; Peetz, A.B.; Zasada, I.A.; Denver, D.R. Genomic evidence for plant-parasitic nematodes as the earliest Wolbachia hosts. Sci. Rep. 2016, 6, 34955. [CrossRef]

12. Haegeman, A.; Vanholme, B.; Jacob, J.; Vandekerckhove, T.T.; Claeys, M.; Borgonie, G.; Gheysen, G. An endosymbiotic bacterium in a plant-parasitic nematode: Member of a new Wolbachia supergroup. Int. J. Parasitol. 2009, 39, 1045-1054. [CrossRef] 
13. Ferri, E.; Bain, O.; Barbuto, M.; Martin, C.; Lo, N.; Uni, S.; Landmann, F.; Baccei, S.G.; Guerrero, R.; de Souza, L.S.; et al. New insights into the evolution of Wolbachia infections in filarial nematodes inferred from a large range of screened species. PLoS ONE 2011, 6, e20843. [CrossRef]

14. Lefoulon, E.; Gavotte, L.; Junker, K.; Barbuto, M.; Uni, S.; Landmann, F.; Laaksonen, S.; Saari, S.; Nikander, S.; de Souza, L.S.; et al. A new type F Wolbachia from Splendidofilariinae (Onchocercidae) supports the recent emergence of this supergroup. Int. J. Parasitol. 2012, 42, 1025-1036. [CrossRef]

15. Baldo, L.; Werren, J.H. Revisiting Wolbachia supergroup typing based on WSP: Spurious lineages and discordance with MLST. Curr. Microbiol. 2007, 55, 81-87. [CrossRef] [PubMed]

16. Bordenstein, S.; Rosengaus, R.B. Discovery of a novel Wolbachia supergroup in Isoptera. Curr. Microbiol. 2005, 51, 393-398. [CrossRef] [PubMed]

17. Glowska, E.; Dragun-Damian, A.; Dabert, M.; Gerth, M. New Wolbachia supergroups detected in quill mites (Acari: Syringophilidae). Infect. Genet. Evol. 2015, 30, 140-146. [CrossRef] [PubMed]

18. Lo, N.; Casiraghi, M.; Salati, E.; Bazzocchi, C.; Bandi, C. How many Wolbachia supergroups exist? Mol. Biol. Evol. 2002, 19, 341-346. [CrossRef] [PubMed]

19. Lo, N.; Paraskevopoulos, C.; Bourtzis, K.; O'Neill, S.L.; Werren, J.H.; Bordenstein, S.R.; Bandi, C. Taxonomic status of the intracellular bacterium Wolbachia pipientis. Int. J. Syst. Evol. Microbiol. 2007, 57, 654-657. [CrossRef]

20. Ros, V.I.D.; Fleming, V.M.; Feil, E.J.; Breeuwer, J.A.J. How diverse is the genus Wolbachia? Multiple-gene sequencing reveals a putatively new Wolbachia supergroup recovered from spider mites (Acari: Tetranychidae). Appl. Environ. Microbiol. 2009, 75, 1036-1043. [CrossRef]

21. Stahlhut, J.K.; Desjardins, C.A.; Clark, M.E.; Baldo, L.; Russell, J.A.; Werren, J.H.; Jaenike, J. The mushroom habitat as an ecological arena for global exchange of Wolbachia. Mol. Ecol. 2010, 19, 1940-1952. [CrossRef] [PubMed]

22. Bennett, G.M.; Pantoja, N.A.; O'Grady, P.M. Diversity and phylogenetic relationships of Wolbachia in Drosophila and other native Hawaiian insects. Fly 2012, 6, 273-283. [CrossRef] [PubMed]

23. Nikoh, N.; Tanaka, K.; Shibata, F.; Kondo, N.; Hizume, M.; Shimada, M.; Fukatsu, T. Wolbachia genome integrated in an insect chromosome: Evolution and fate of laterally transferred endosymbiont genes. Genome Res. 2008, 18, 272-280. [CrossRef]

24. Leclercq, S.; Thézé, T.; Chebbi, M.A.; Giraud, I.; Moumen, B.; Ernenwein, L.; Grève, P.; Gilbert, C.; Cordaux, R. Birth of a W sex chromosome by horizontal transfer of Wolbachia bacterial symbiont genome. Proc. Natl. Acad. Sci. USA 2016, 113, 15036-15041. [CrossRef]

25. Fenn, K.; Blaxter, M. Are filarial nematode Wolbachia obligate mutualist symbionts? Trends Ecol. Evol. 2004, 19, 163-166. [CrossRef]

26. Balvín, O.; Roth, S.; Talbot, B.; Reinhardt, K. Co-speciation in bedbug Wolbachia parallel the pattern in nematode hosts. Sci. Rep. 2018, 8, 8797. [CrossRef]

27. Serbus, L.R.; Casper-Lindley, C.; Landmann, F.; Sullivan, W. The genetics and cell biology of Wolbachia-host interactions. Annu. Rev. Genet. 2008, 42, 683-707. [CrossRef]

28. Gebiola, M.; Giorgini, M.; Kelly, S.E.; Doremus, M.R.; Ferree, P.M.; Hunter, M.S. Cytological analysis of cytoplasmic incompatibility induced by Cardinium suggests convergent evolution with its distant cousin Wolbachia. Proc. Biol. Sci. 2017, $284,20171433$. [CrossRef]

29. Singh, N.D. Wolbachia infection associated with increased recombination in Drosophila. G3 (Bethesda) 2019, 9, 229-237. [CrossRef] [PubMed]

30. Becking, T.; Chebbi, M.A.; Giraud, I.; Moumen, B.; Laverré, T.; Caubet, Y.; Peccoud, J.; Gilbert, C.; Cordaux, R. Sex chromosomes control vertical transmission of feminizing Wolbachia symbionts in an isopod. PLoS Biol. 2019, 17, e3000438. [CrossRef]

31. Xi, Z.; Khoo, C.C.; Dobson, S.L. Wolbachia establishment and invasion in an Aedes aegypti laboratory population. Science 2005, 310, 326-328. [CrossRef] [PubMed]

32. Foster, J.; Ganatra, M.; Kamal, I.; Ware, J.; Makarova, K.; Ivanova, N.; Bhattacharyya, A.; Kapatral, V.; Kumar, S.; Posfai, J.; et al. The Wolbachia genome of Brugia malayi: Endosymbiont evolution within a human pathogenic nematode. PLoS Biol. 2005, 3, e12. [CrossRef] [PubMed]

33. Sahoo, R.K.; Lohman, D.J.; Wahlberg, N.; Müller, C.J.; Brattström, O.; Collins, S.C.; Peggie, D.; Aduse-Poku, K.; Kodandaramaiah, U. Evolution of Hypolimnas butterflies (Nymphalidae): Out-of-Africa origin and Wolbachia-mediated introgression. Mol. Phylogenet. Evol. 2018, 123, 50-58. [CrossRef]

34. Ouvrard, D. Psyl'list-The World Psylloidea Database. 2021. Available online: http://www.hemiptera-databases.com/psyllist (accessed on 20 July 2021).

35. Guidolin, A.S.; Cônsoli, F.L. Molecular characterization of Wolbachia strains associated with the invasive Asian citrus psyllid Diaphorina citri in Brazil. Microb. Ecol. 2013, 65, 475-486. [CrossRef] [PubMed]

36. Fromont, C.; Riegler, M.; Cook, J.M. Phylogeographic analyses of bacterial endosymbionts in fig homotomids (Hemiptera: Psylloidea) reveal codiversification of both primary and secondary endosymbionts. FEMS Microbiol. Ecol. 2016, 92 , fiw205. [CrossRef]

37. Hodkinson, I. Present-Day Distribution patterns of the Holarctic Psylloidea (Homoptera: Insecta) with particular reference to the origin of the Nearctic fauna. J. Biogeogr. 1980, 7, 127-146. [CrossRef]

38. Hollis, D. Australian Psylloidea: Jumping Plantlice and Lerp Insects; Australian Biological Resources Study: Canberra, Australia, 2004; p. 216. 
39. Drohojowska, J.; Kalandyk-Kołodziejczyk, M.; Simon, E. Thorax morphology of selected species of the genus Cacopsylla (Hemiptera, Psylloidea). ZooKeys 2013, 319, 27-35. [CrossRef]

40. Hodkinson, I.D. New psyllids from Canada (Homoptera: Psyllidae). Zool. J. Linn. Soc. 1976, 58, 321-330. [CrossRef]

41. Hodkinson, I.D. The psyllids (Homoptera-Psyllidae) of Alaska. Syst. Entomol. 1978, 3, 333-360. [CrossRef]

42. Hodkinson, I.D. Facultative parthenogenesis in Psylla myrtilli Wagner (Hom., Psyllidae): The saga continues in Norway. Fauna Norvegica (B) 1983, 30, 1-2.

43. Nokkala, S.; Maryańska-Nadachowska, A.; Kuznetsova, V.G. First evidence of polyploidy in Psylloidea (Homoptera, Sternorrhyncha): A parthenogenetic population of Cacopsylla myrtilli (W. Wagner, 1947) from northeast Finland is apomictic and triploid. Genetica 2008, 133, 201-205. [CrossRef]

44. Nokkala, C.; Kuznetsova, V.G.; Nokkala, S. Meiosis in rare males in parthenogenetic Cacopsylla myrtilli (Wagner, 1947) (Hemiptera, Psyllidae) populations from northern Europe. Comp. Cytogenet. 2013, 7, 241-251. [CrossRef] [PubMed]

45. Nokkala, C.; Kuznetsova, V.G.; Nokkala, S. Rare diploid females coexist with rare males: A novel finding in triploid parthenogenetic populations in the psyllid Cacopsylla myrtilli (W.Wagner, 1947) (Hemiptera, Psylloidea) in northern Europe. Genetica 2015, 143, 589-595. [CrossRef]

46. Nokkala, S.; Kuznetsova, V.G.; Nokkala, C. Characteristics of parthenogenesis in Cacopsylla ledi (Flor, 1861) (Hemiptera, Sternorryncha, Psylloidea): Cytological and molecular approaches. Comp. Cytogenet. 2017, 11, 807-817. [CrossRef]

47. Nokkala, C.; Kuznetsova, V.G.; Rinne, V.; Nokkala, S. Description of two new species of the genus Cacopsylla Ossiannilsson, 1970 (Hemiptera, Psylloidea) from northern Fennoscandia recognized by morphology, cytogenetic characters and COI barcode sequence. Comp. Cytogenet. 2019, 13, 367-382. [CrossRef] [PubMed]

48. Labina, E.S.; Nokkala, S.; Maryańska-Nadachowska, A.; Kuznetsova, V.G. The distribution and population sex ratio of Cacopsylla myrtilli (W. Wagner, 1947) (Hemiptera: Psylloidea). Folia Biol. (Krakow) 2009, 57, 157-163. [CrossRef] [PubMed]

49. Kuznetsova, V.G.; Labina, E.S.; Shapoval, N.A.; Maryańska-Nadachowska, A.; Lukhtanov, V.A. Cacopsylla fraudatrix sp.n. (Hemiptera: Psylloidea) recognised from testis structure and mitochondrial gene COI. Zootaxa 2012, 3547, 55-63. [CrossRef]

50. Zhou, W.; Rousset, F.; O'Neil, S. Phylogeny and PCR- based classification of Wolbachia strains using wsp gene sequences. Proc. Biol. Sci. 1998, 265, 509-515. [CrossRef] [PubMed]

51. Werren, J.H.; Windsor, D.M. Wolbachia infection frequency in insects: Evidence of a global equilibrium? Proc. R. Soc. Lond. B Biol. Sci. 2000, 267, 1277-1285. [CrossRef] [PubMed]

52. Kearse, M.; Moir, R.; Wilson, A.; Stones-Havas, S.; Cheung, M.; Sturrock, S.; Buxton, S.; Cooper, A.; Markowitz, S.; Duran, C.; et al. Geneious basic: An integrated and extendable desktop software platform for the organization and analysis of sequence data. Bioinformatics 2012, 28, 1647-1649. [CrossRef]

53. Hall, T. BioEdit: An important software for molecular biology. GERF Bull. Biosci. 2011, 2, 60-61.

54. Ronquist, F.; Teslenko, M.; van der Mark, P.; Ayres, D.L.; Darling, A.; Höhna, S.; Larget, B.; Liu, L.; Suchard, M.A.; Huelsenbeck, J.P. MrBayes 3.2: Efficient Bayesian phylogenetic infer- ence and model choice across a large model space. Syst. Biol. 2012, 61, 539-542. [CrossRef] [PubMed]

55. Darriba, D.; Taboada, G.L.; Doallo, R.; Posada, D. JModelTest 2: More models, new heuristics and parallel computing. Nat. Methods 2012, 9, 772. [CrossRef] [PubMed]

56. Werren, J.H.; Zhang, W.; Guo, L.R. Evolution and phylogeny of Wolbachia: Reproductive parasites of arthropods. Proc. Biol. Sci. 1995, 261, 55-63. [CrossRef]

57. Ritter, S.; Michalski, S.G.; Settele, G.; Wiemers, M.; Fric, Z.F.; Sielezniew, M.; Šašic, M.; Rozier, Y. Wolbachia infections mimic cryptic speciation in two parasitic butterfly species, Phengaris teleius and P. nausithous (Lepidoptera: Lycaenidae). PLoS ONE 2013, 8, e78107. [CrossRef]

58. Sucháčková Bartoňová, A.; Konvička, M.; Marešová, J.; Wiemers, M.; Ignatev, N.; Wahlberg, N.; Schmitt, T.; Fric, Z.F. Wolbachia affects mitochondrial population structure in two systems of closely related Palaearctic blue butterflies. Sci. Rep. 2021, 11, 3019. [CrossRef] [PubMed]

59. Rousset, F.; de Stordeur, E. Properties of Drosophila simulans strains experimentally infected by different clones of the bacterium Wolbachia. Heredity 1994, 72, 325-331. [CrossRef] [PubMed]

60. Detcharoen, M.; Arthofer, W.; Schlick-Steiner, B.C.; Steiner, F.M. Wolbachia megadiversity: 99\% of these microorganismic manipulators unknown. FEMS Microbiol. Ecol. 2019, 95, fiz151. [CrossRef]

61. Jolley, K.A.; Bray, J.E.; Maiden, M.C.J. Open-access bacterial population genomics: BIGSdb software, the PubMLST.org website and their applications [version 1; peer review: 2 approved]. Wellcome Open Res. 2018, 3, 124. [CrossRef] [PubMed]

62. Camerota, C.; Raddadi, N.; Pizzinat, A.; Gonella, E.; Crotti, E.; Tedeschi, R.; Mozes-Daube, N.; Ember, I.; Acs, Z.; Kolber, M.; et al. Incidence of 'Candidatus Liberibacter europaeus' and phytoplasmas in Cacopsylla species (Hemiptera: Psyllidae) and their host/shelter plants. Phytoparasitica 2012, 40, 213-221. [CrossRef]

63. Cen, Y.; Zhang, L.; Xia, Y.; Guo, J.; Deng, X.; Zhou, W.; Sequeira, R.; Gao, J.; Wang, Z.; Yue, J.; et al. Detection of 'Candidatus Liberibacter Asiaticus' in Cacopsylla (Psylla) citrisuga (Hemiptera: Psyllidae). Fla. Entomol. 2012, 95, 304-311. [CrossRef]

64. Cooper, W.R.; Garczynski, S.F.; Horton, D.R.; Unruh, T.R.; Beers, E.H.; Peter, W.S.; Hilton, R.J. Bacterial Endosymbionts of the Psyllid Cacopsylla pyricola (Hemiptera: Psyllidae) in the Pacific Northwestern United States. Environ. Entomol. 2017, 46, 393-402. [CrossRef] [PubMed] 
65. Morrow, J.L.; Om, N.; Beattie, G.A.C.; Chambers, G.A.; Donovan, N.J.; Liefting, L.W.; Riegler, M.; Holford, P. Characterization of the bacterial communities of psyllids associated with Rutaceae in Bhutan by high throughput sequencing. BMC Microbiol. 2020, 20, 215. [CrossRef]

66. Sun, X.; Cui, L.; Li, Z. Diversity and phylogeny of Wolbachia infecting Bactrocera dorsalis (Diptera: Tephritidae) populations from China. Environ. Entomol. 2007, 36, 1283-1289. [CrossRef]

67. Arthofer, W.; Riegler, M.; Schneider, D.; Krammer, M.; Miller, W.J.; Stauffer, C. Hidden Wolbachia diversity in field populations of the European cherry fruit fly, Rhagoletis cerasi (Diptera, Tephritidae). Mol. Ecol. 2009, 18, 3816-3830. [CrossRef]

68. Hughes, G.L.; Allsopp, P.G.; Brumbley, S.M.; Woolfit, M.; McGraw, E.A.; O’Neill, S.L. Variable infection frequency and high diversity of multiple strains of Wolbachia pipientis in Perkinsiella planthoppers. Appl. Environ. Microbiol. 2011, 77, 2165-2168. [CrossRef]

69. Arthofer, W.; Riegler, M.; Avtzis, D.N.; Stauffer, C. Evidence for low-titre infections in insect symbiosis: Wolbachia in the bark beetle Pityogenes chalcographus (Coleoptera, Scolytinae). Environ. Microbiol. 2009, 11, 1923-1933. [CrossRef]

70. Mascarenhas, R.O.; Prezotto, L.F.; Perondini, A.L.P.; Marino, C.L.; Selivon, D. Wolbachia in guilds of Anastrepha fruit flies (Tephritidae) and parasitoid wasps (Braconidae). Genet. Mol. Biol. 2016, 39, 600-610. [CrossRef]

71. Chu, C.; Hoffmann, M.; Braswell, W.E.; Pelz-Stelinski, K.S. Genetic variation and potential coinfection of Wolbachia among widespread Asian citrus psyllid (Diaphorina citri Kuwayama) populations. Insect Sci. 2019, 26, 671-682. [CrossRef]

72. Sintupachee, S.; Milne, J.R.; Poonchaisri, S.; Baimai, V.; Kittayapong, P. Closely related Wolbachia strains within the pumpkin arthropod community and the potential for horizontal transmission via the plant. Microb. Ecol. 2006, 51, 294-301. [CrossRef]

73. Gutzwiller, F.; Dedeine, F.; Kaiser, W.; Giron, D.; Lopez-Vaamonde, C. Correlation between the green-island phenotype and Wolbachia infections during the evolutionary diversification of Gracillariidae leaf-mining moths. Ecol. Evol. 2015, 5, 18, 4049-4062. [CrossRef] [PubMed] 